\title{
Experimental investigation of miscibility conditions of dead and live asphaltenic crude oil- $\mathrm{CO}_{2}$ systems
}

\author{
Abdolah Golkari ${ }^{1} \cdot$ Masoud Riazi $^{2}$
}

Received: 23 December 2015/ Accepted: 31 July 2016/Published online: 27 September 2016

(c) The Author(s) 2016. This article is published with open access at Springerlink.com

\begin{abstract}
Carbon dioxide $\left(\mathrm{CO}_{2}\right)$ injection is a well-established enhanced oil recovery method. The optimization process of $\mathrm{CO}_{2}$ injection is usually performed through estimation of two physical properties, i.e., minimum miscibility and first-contact miscibility pressures (MMP and FCMP) for the crude oil- $\mathrm{CO}_{2}$ system. In this experimental study, the equilibrium IFT of the crude oil- $\mathrm{CO}_{2}$ system is measured at ( 313.15 and $323.15 \mathrm{~K}$ ) for two oil types (i.e., live and dead crude oil) using the axisymmetric pendant drop shape analysis method. Vanishing interfacial tension technique is also applied to estimate the MMP and FCMP. The experimental results demonstrate that IFT decreases with different trends as the equilibrium pressure increases for the systems of live oil/ $/ \mathrm{CO}_{2}$ and dead oil/ $/ \mathrm{CO}_{2}$ systems. The IFT test results demonstrate that the estimated MMP and FCMP values of crude oil- $\mathrm{CO}_{2}$ system increase with temperature. It was also observed that the presence of methane gas in the oil phase increases the MMP value, whereas it decreases the FCMP.
\end{abstract}

Keywords Carbon dioxide- $\left(\mathrm{CO}_{2}\right)$ enhanced oil recovery (EOR) process - Minimum miscibility pressure (MMP) . First-contact miscibility pressure (FCMP) · Vanishing interfacial tension (VIT) method $\cdot$ Live asphaltenic oil

Masoud Riazi

mriazi@shirazu.ac.ir

1 Department of Chemical Engineering, School of Chemical and Petroleum Engineering, Shiraz University, Shiraz, Iran

2 Enhanced Oil Recovery (EOR) Research Centre, School of Chemical and Petroleum Engineering, Shiraz University, Shiraz, Iran

\author{
Abbreaviations \\ API Oil API gravity (American Petroleum Institute) \\ ADSA Axisymmetric drop shape analysis \\ FCMP First-contact miscibility pressure (MPa) \\ GOR Gas-oil ratio (scf/bbl) \\ IFT Interfacial tension $(\mathrm{mN} / \mathrm{m})$ \\ MMP Minimum miscibility pressure (MPa) \\ $P \quad$ Pressure (MPa) \\ $T \quad$ Temperature (K) \\ VIT Vanishing interfacial tension
}

\section{Introduction}

Enhanced oil recovery (EOR) methods become important and get attentions in petroleum industry. For this purpose, gas injection as an efficient enhanced oil recovery technique has been utilized to recover the remaining oil in place by reduction of the interfacial tension and viscosity and maintaining the reservoir pressure (Jha 1985; Rojas and Ali 1988). Among of the existed gases, use of the carbon dioxide $\left(\mathrm{CO}_{2}\right)$ is one of the proposed methods with relatively low cost and high efficiency to improve oil recovery (Ali and Thomas 1996; Alvarado and Manrique 2010; Moritis 2004). $\mathrm{CO}_{2}$ injection method has been suggested for processes of enhanced oil recovery and $\mathrm{CO}_{2}$ sequestration (Aycaguer et al. 2001; Kokal et al. 1992; Mathiassen 2003; Sarma 2003). In addition, $\mathrm{CO}_{2}$ injection process is more attracted due to the reduction of greenhouses gas emissions (Aycaguer et al. 2001; Gui et al. 2010; Rao and Rubin 2002). The $\mathrm{CO}_{2}$ flooding process, depending on the highest possible operating pressure and minimum miscible conditions, can be performed at both 
miscibility and immiscibility conditions (Wang and $\mathrm{Gu}$ 2011). The oil recovery mechanisms that occur in $\mathrm{CO}_{2}$ injection include the oil viscosity reduction, light-component extraction, IFT reduction, immiscible and miscible displacements and improving the oil swelling (Cao 2012; Holm and Josendal 1974; Mungan 1981; Simon and Graue 1965). These mechanisms could play key roles, depending on whether the $\mathrm{CO}_{2}$ displacement is miscible or immiscible. For instance, in immiscible $\mathrm{CO}_{2}$ injection process the oil viscosity and IFT reduce, these two mechanisms are among the important oil recovery mechanisms, whereas the oil-swelling, and light-components extraction take place in miscible $\mathrm{CO}_{2}$ flooding process (Martin and Taber 1992).

If the pressure of the injecting fluid increases, the IFT between flooded fluid (i.e., gas) and oil in reservoir approaches to zero and consequently capillary force decreases to a minimum value (Danesh 1998; Lake 1989). Under this condition, the injecting gas will be able to mobilize a great amount of trapped oil at pore scale (Green and Willhite 1998; Stalkup Jr 1983). Miscibility conditions mainly depends on pressure, temperature and the fluids compositions. It is a condition at which two fluids can be mixed together so that no separation can be identified (Green and Willhite 1998; Orr and Jessen 2007). In general, the mechanisms of oil recovery under miscible conditions are mainly reduction of both capillary pressure and reservoir fluid viscosity (Leach and Yellig 1981; Wylie and Mohanty 1999; Zanganeh et al. 2012). From operational point of view, the minimum miscibility pressure (MMP) is the minimum operating pressure at which oil recovery is high and displacing gas with reservoir oil can reach miscibility at reservoir conditions (Cao and Gu 2013b; Dong et al. 2001; Stalkup 1987). MMP is a key factor on enhanced oil recovery (EOR) method including $\mathrm{CO}_{2}$ or hydrocarbon $(\mathrm{HC})$ miscible gas flood (Ghorbani et al. 2014). Thus, a precise MMP estimation would be a favorite tool for reservoir engineers to better predict the performance of the gas injection process. MMP can be divided into multiple contact miscibility pressure (MCMP) and first-contact miscibility pressure (FCMP). In the former, the miscibility condition is achieved during mass transfer between the gas and the oil phase (i.e., exchanging components) through which the physical properties of two phases become close to each other. In the latter (i.e., FCMP), the two phases create a single phase at the lowest possible pressure at which the two phases mixed in any proportion when first brought into contact (Schlumberger 2016). Pressure conditions of MCMP are smaller than those of FCMP (Farzad and Amani 2012; Holm 1987; Orr and Jessen 2007). In this study, MMP is used instead of multiple contact miscibility pressure.
Condition of first-contact miscibility for reservoir gas flooding depends on the composition of the flooded gas, composition of oil, and temperature (Green and Willhite 1998; Gu et al. 2013). When the injection pressure is adequately high, the injected $\mathrm{CO}_{2}$ can become miscible with the trapped oil when brought into the first contact. Such pressure is known as the first-contact miscibility pressure (De Gennes et al. 2004; Holm 1987). When the reservoir pressure is less than the MMP, the gas injection would be an immiscible injection process with low efficiency (Fanchi 2005). Therefore, it would be difficult to reach the lowest possible pressure under which miscibility conditions can occur (Kazemzadeh et al. 2015).

$\mathrm{Gu}$ et al. (2013) by measuring the IFT of the light crude oil- $\mathrm{CO}_{2}$ system estimated the MMP and FCMP of the light dead oil- $-\mathrm{CO}_{2}$ and light live oil- $\mathrm{CO}_{2}$ systems. They concluded that estimated MMP and FCMP increase with temperature for the live/dead light oil- $\mathrm{CO}_{2}$ systems. In addition, the temperature effect on FCMP is higher than that on MMP. They also resulted that the effect of oil composition on the estimated MMP and FCMP is assessable. In addition, their results show that the temperature effects on the MMP and FCMP for a given crude oil- $\mathrm{CO}_{2}$ system are strong. The main purpose of this experimental study is to investigate the behavior of $\mathrm{CO}_{2}$ miscibility conditions using dead and live asphaltenic crude oil and also to compare the results with light crude oil in the literature (Gu et al. 2013).

There are three main experimental techniques to determine fluids miscibility under reservoir conditions. The first two techniques are measuring the minimum miscibility pressure (MMP) using the slim-tube displacement and the rising bubble apparatus (RBA) (Dong et al. 2001; Elsharkawy et al. 1992; Ghorbani et al. 2014; Kazemzadeh and Riazi 2013). The third technique of miscibility is predicted by IFT measurement. This method is known as vanishing interfacial tension (VIT) technique (i.e., IFT disappearance method). VIT technique was first proposed by Rao (1997) and Rao and Lee (2002, 2003). This method contains determining IFT between the injecting gas and the reservoir oil at reservoir conditions (Cao and Gu 2013b; Green and Willhite 1998; Holm 1987; Kazemzadeh and Riazi 2013; Stalkup Jr 1983). The MMP is recently determined by the VIT (vanishing interfacial tension) method with reasonable accuracy (Rao and Lee 2000a, b; Rao and Lee 2002). In this method, when the fluids become miscible, the equilibrium interfacial tension between the involved phases would approach zero. The researchers also demonstrated that the zero interfacial tension is an essential condition to reach to the miscibility conditions (Benham et al. 1960; Holm 1987). The estimating MMP by utilizing the VIT method can be accomplished at shorter period of time. This can be one of the advantages of this technique 
knowing that the slim-tube method for same test usually takes few weeks (Elsharkawy et al. 1992). Besides the aforementioned advantage, it should be noted that VIT uses extrapolation to determine miscibility. That is, the system always contains two phases and the pressure never experimentally reaches the point of zero IFT. In contrast, both slim tube and RBA do not use extrapolation and can both cover the pressure of interest. RBA is also a fast method compared to slim tube.

Nobakht et al. presented that the equilibrium IFT of $\mathrm{CO}_{2}$-oil system often decreases linearly with pressure, and then it slightly reduces at higher pressure (at the second pressure range). They observed several important mechanisms such as the oil-swelling process, the light-components extraction, and the subsequent weak lightcomponents extraction. They also observed that light oil components leave from the oil drop and enter the gas bulk when the equilibrium pressure is higher than the onset pressure (Nobakht et al. 2008a, b).

Rao and Lee estimated the MMP of live crude oil with several gas mixtures using various techniques. In addition, they investigated the influence of pressure on interfacial tension between live oil and three gas solvents at temperature of $369.15 \mathrm{~K}$ (the reservoir conditions). They concluded that the VIT method has favorable applications due to its visualization, quickly and cost usefulness. They showed that MMPs estimated from the VIT method had $3-5 \%$ difference from those observed visually in the cell (Rao and Lee 2003).

Saini and Rao measured the equilibrium IFT between two samples of recombined live oil provided from stock tank of a Mississippi oil field and $\mathrm{CO}_{2}$ extra purity at reservoir conditions (i.e., temperature of $415.93 \mathrm{~K}$ and different pressures up to $17.878 \mathrm{MPa}$ ). They also estimated MMP of the same system at $415.93 \mathrm{~K}$ using dispersion-free MMP in an independently conducted (equation of state) EOS modeling study (tuned to match black oil property data set with 15 components) based on the vanishing tie line method. They used the VIT method and equation of state for defining the minimum miscibility pressure. They indicated that the difference between MMP estimated by VIT method and EOS-estimated dispersion-free is lower than $4 \%$ (Saini and Rao 2010).

In another experimental work, Zolghadr et al. investigated the MMP conditions of three oil fluids and $\mathrm{CO}_{2}$ systems at five various temperatures. Their results showed that MMP increases with temperature. They also observed that MMP of heavier paraffinic hydrocarbon (i.e., hexadecane) and $\mathrm{CO}_{2}$ almost is close to the MMP of diesel fuel/ $\mathrm{CO}_{2}$ system. In addition, they concluded that the slopes of the interfacial tension (IFT) of two kinds of used paraffinic hydrocarbons and $\mathrm{CO}_{2}$ versus pressure were the same at each test temperature, but were different from that of VIT curve between diesel fuel and $\mathrm{CO}_{2}$ at high pressures (Zolghadr et al. 2013).

During the miscible $\mathrm{CO}_{2}$ injection process, the asphaltene precipitation phenomenon occurs in asphaltenic oil samples (Escrochi et al. 2013; Jafari Behbahani et al. 2012; Zanganeh et al. 2012). Asphaltene is the heaviest component of the crude oil that is not soluble in n-heptane and n-pentane but is soluble in toluene (Ferworn et al. 1993; Nielsen et al. 1994). In the literature, several investigations of $\mathrm{CO}_{2}$-asphaltenic crude oil IFT versus pressure have been performed. The observed results show different linear slopes at different temperatures (Escrochi et al. 2013; Wang and $\mathrm{Gu}$ 2011). The starting point of slope variation of the VIT curve corresponds to the onset of the asphaltene precipitation (Escrochi et al. 2013). In the VIT method, asphaltene precipitation does not affect the MMP estimation that is one of the advantages of this technique compared to other existing methods (Hemmati-Sarapardeh et al. 2014; Wang et al. 2010). In this study, the vanishing interfacial tension method is used to estimate the MMP and the FCMP of dead and live asphaltenic crude oil/ $/ \mathrm{CO}_{2}$ systems at two temperatures. The effect of temperature and oil composition (presence of methane gas in the oil phase at $P=4 \mathrm{MPa}$ ) on $\mathrm{CO}_{2}$ miscibility conditions using a crude asphaltenic dead/live oil is investigated.

\section{Materials and methods}

\section{Materials}

In this experimental work, the crude oil supplied from one of the southern Iranian oil reservoir. The general specifications of the crude oil are shown in Table 1. Carbon dioxide and methane (with a purity of more than $99.95 \%$ ) were prepared from a local company.

\section{Preparing the live oil sample}

Due to the methane gas forms the main part from gases existing in oil reservoir. The live crude oil was prepared by mixing dead crude oil with $\mathrm{CH}_{4}$ gas. The experimental process for preparing the live asphaltenic oil sample is discussed as follows. A high-pressure cylinder-piston with the volume of $500 \mathrm{~cm}^{3}$ was cleaned and maintained in an oven that fixed at $T=313.15 \mathrm{~K}$. Crude oil sample with volume of $300 \mathrm{~cm}^{3}$ was transferred within the cylinderpiston by a high-pressure pump. Then, the methane gas was slowly injected into the oil tank until the pressure of its content reached at $P=4 \mathrm{MPa}$. In fact, working with the oil type is based on calculation of the minimum gas-oilratio (GOR) at $P=4 \mathrm{MPa}$. Eventually, the high-pressure cylinder-piston comprising the dead crude oil-methane gas 
Table 1 General properties and composition analysis of the crude oil ("NISOC Report, Ahvaze. south of Iran" 2014)

\begin{tabular}{lll}
\hline Specification & Unit & Value \\
\hline Gravity of dead oil & ${ }^{\circ} \mathrm{API}$ & 24.46 \\
Saturates & (Mass fraction) & 0.4268 \\
Aromatics & (Mass fraction) & 0.4069 \\
Resins & (Mass fraction) & 0.0763 \\
Asphaltene & (Mass fraction) & 0.0900 \\
$\mathrm{C}_{1}$ & (Mole fraction) & 0.0000 \\
$\mathrm{C}_{2}$ & (Mole fraction) & 0.0016 \\
$\mathrm{C}_{3}$ & (Mole fraction) & 0.0033 \\
$\mathrm{iC}_{4}$ & (Mole fraction) & 0.0017 \\
$\mathrm{nC}_{4}$ & (Mole fraction) & 0.0041 \\
$\mathrm{iC}_{5}$ & (Mole fraction) & 0.0030 \\
$\mathrm{nC}_{5}$ & (Mole fraction) & 0.0033 \\
$\mathrm{C}_{6}$ & (Mole fraction) & 0.0483 \\
$\mathrm{C}_{7}$ & (Mole fraction) & 0.0740 \\
$\mathrm{C}_{8}$ & (Mole fraction) & 0.0790 \\
$\mathrm{C}_{9}$ & (Mole fraction) & 0.0722 \\
$\mathrm{C}_{10}$ & (Mole fraction) & 0.0676 \\
$\mathrm{C}_{11}$ & (Mole fraction) & 0.0413 \\
$\mathrm{C}_{12}{ }^{+}$ & (Mole fraction) & 0.6006 \\
$\mathrm{C}_{12}{ }^{+}$molecular weight & & 326 \\
$\mathrm{C}_{12}{ }^{+}$density at 288.15 K & g/mL & 0.9355 \\
\hline
\end{tabular}

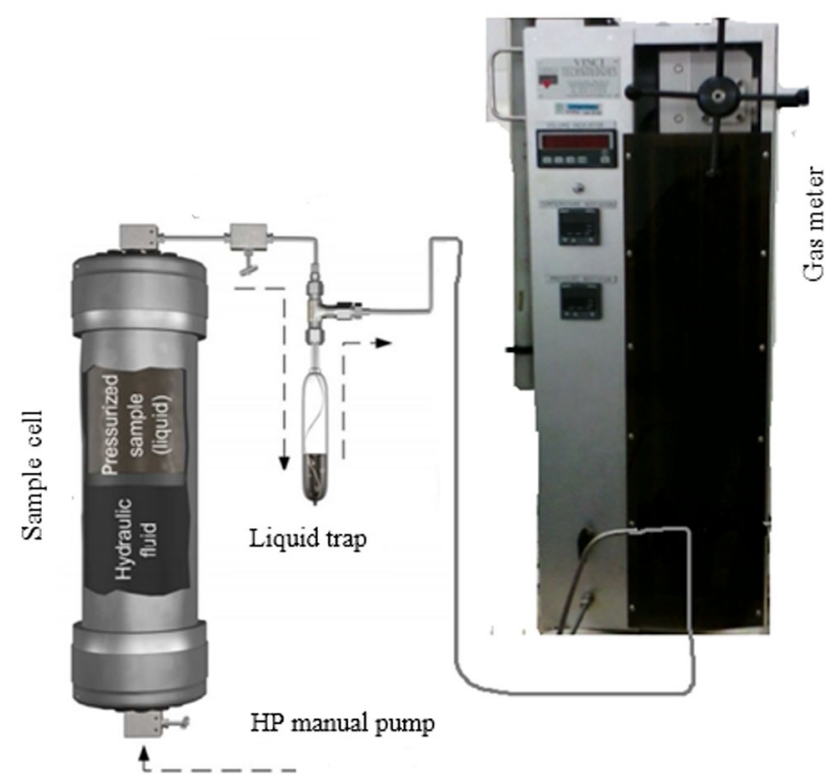

Fig. 1 Schematic diagram for the measurement of GOR

had been shaking for at least 10 days to make sure that the dead oil is fully mixed with the methane gas. In addition, the above steps were repeated at $T=323.15 \mathrm{~K}$ and $P=4 \mathrm{MPa}$. To estimate the volume of dissolved gas in oil a gas meter was used. Figure 1 shows a schematic diagram
Table 2 Measured GOR at $P=4 \mathrm{MPa}$ and two temperatures

\begin{tabular}{ll}
\hline Temperature/K & GOR $(\mathrm{Scf} / \mathrm{bbl})$ \\
\hline 313.15 & 70.46 \\
323.15 & 64.21 \\
\hline
\end{tabular}

of the experimental setup of the gas meter. A sample cell maintained the prepared live oil at desired conditions (i.e., single phase conditions at two temperatures and saturation pressure). The pressure inside the sample cell was controlled by a high-pressure (HP) manual pump. The liquid phase is collected at the bottom of glass vessel, and the liberated gas from the oil sample is collected in the gas meter. A high-pressure steel tubing connected the sample vessel to the gas meter. The process of gas separation from the sample oil continues for about $30 \mathrm{~min}$, during which the pressure of the system is slowly reduced to atmospheric.The results of GOR are shown in Table 2. In this table, they are reported as the ratio of the volume of gas (at standard conditions) to the volume of liquid in the sample (stock tank conditions).

Thus, before the injection of live crude oil prepared inside the high-pressure cell, the live crude oil-methane gas within the high-pressure cylinder was further pressurized up to the pressure of $4.8 \mathrm{MPa}$, which was above the mixing pressure to avoid gas liberation during the experiments. In this study, all interfacial tension measurements at two temperature start from pressure of $4.82 \mathrm{MPa}$ that is above the saturation pressure of the live oil. Hence, cylinderpiston-containing live oil was used vertically to measure the interfacial tension.

\section{IFT measurements}

A schematic of the IFT 700 apparatus is shown in Fig. 2. This rig has been designed and manufactured by VINCI Technologies France to determine the dynamic and equilibrium IFT of the dead/live crude oil- $\mathrm{CO}_{2}$ systems using the axisymmetric drop shape analysis (ADSA) method for the pendant oil drop (Cheng et al. 1990; Rotenberg et al. 1983). The main component of this system includes a view cell with volume of $20 \mathrm{~cm}^{3}$ in which the two immiscible phases (drop phase and bulk phase) are brought in direct contact. The drop shape could be monitored through two high-pressure windows fixed at both sides of the cell. A source of light, which is installed in front of the view glasses, provides the required light for the camera to monitor the drop shape. The drop shape is analyzed using the installed software on a personal computer to estimate the gas-oil IFT. In this apparatus, two storing tanks for fluids are connected to the high-pressure cell. To form a pendant drop, a needle made of steel is contacted to the top of the cell (Zolghadr 2011; Zolghadr et al. 2013). 


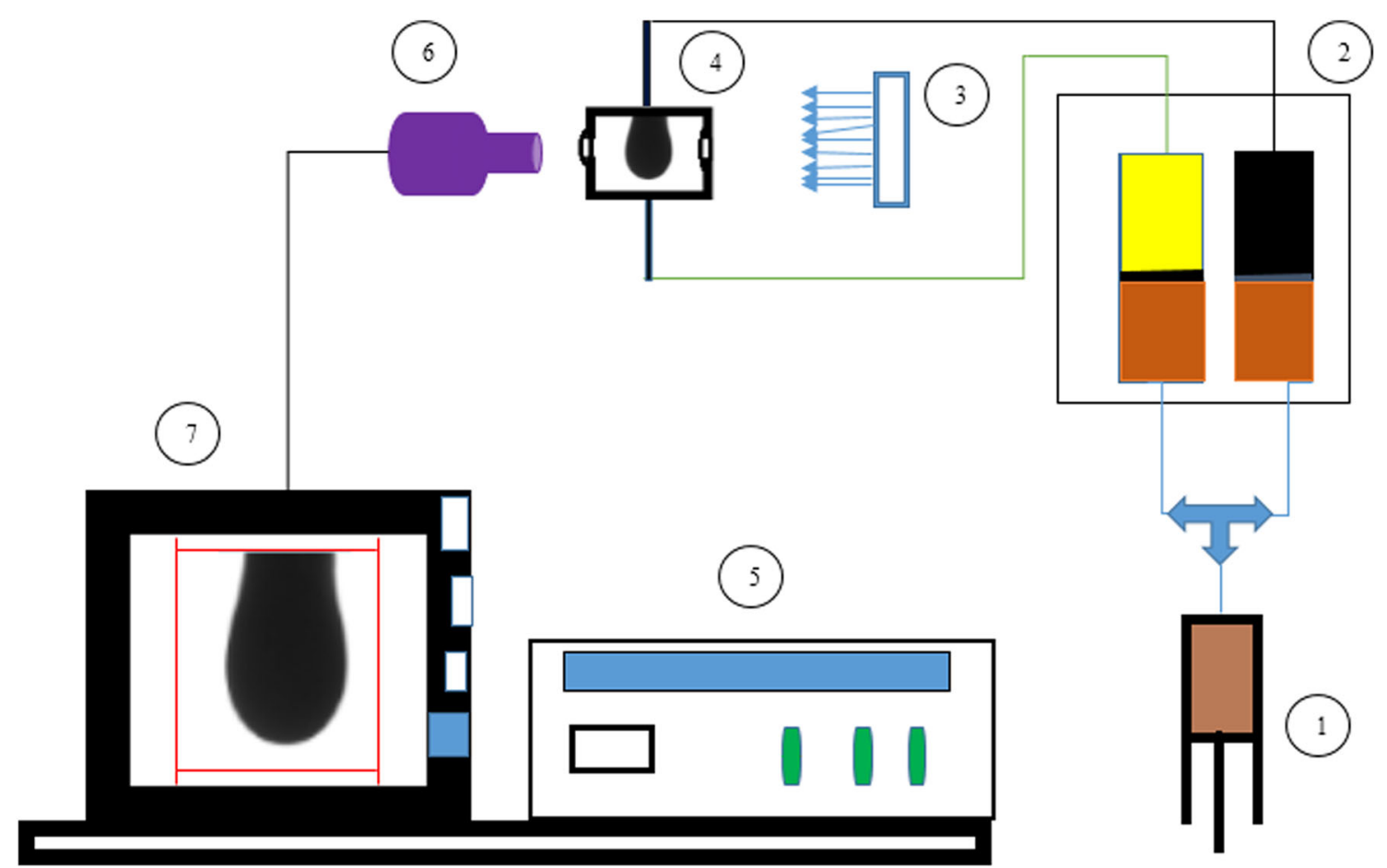

Fig. 2 Experimental apparatus for IFT measurement. 1 Pressure generator, 2 bulk and drop tanks, 3 light source, 4 high pressure cell, 5 pressure and temperature display unit, $6 \mathrm{CCD}$ camera, 7 personal computer

A manual pump is used to keep the view cell pressure at the required conditions. The total system is protected by a heating jacket to set a constant temperature condition. Using a manual pump, the crude oil was injected into the drop fluid storage tank (DT) and the $\mathrm{CO}_{2}$ was injected into the bulk fluid storage tank (BT) (IFT 700 2013). Furthermore, a manual pump is used to inject the gas into the cell and to pressurize it at a desired pressure. The whole system is given a sufficient time (i.e., about $45 \mathrm{~min}$ ) to reach the equilibrium conditions. The accuracy of cell equilibrium pressure is about of $0.05 \mathrm{MPa}$. Then, the temperatures of the oil and $\mathrm{CO}_{2}$ tanks and the view cell were controlled using two electrical sensors (PT 100) that are located in the storage tank and the view cell with accuracy of $0.1 \mathrm{~K}$. The required heating of the view cell and storage tanks is supplied by some heating elements that are placed in the holes of the vessel wall. The oil drop is injected from the top of the cell to introduce a pendant drop in the $\mathrm{CO}_{2}$ bulk. The dynamic IFT is measured once the drop formed. Interfacial tension of the crude oil- $\mathrm{CO}_{2}$ system is estimated using a drop shape analysis software based on the shape of the pendant drop. The variations of dynamic IFT versus time of the oil drop with the $\mathrm{CO}_{2}$ was measured and recorded until it reached the equilibrium conditions. This was due to the diffusion of $\mathrm{CO}_{2}$ into the pendant oil drop and the extraction of light components of oil by
$\mathrm{CO}_{2}$. The average of the dynamic IFT data in the last $100 \mathrm{~s}$ is determined and presented as the equilibrium IFT at desired pressure and temperature conditions (Nobakht et al. 2008a). Some oil drops are located at bottom of the cell before injecting gas into the cell to attain the equilibrium conditions more quickly. The input data of the mentioned software are the densities of two phases involved and calibrating needle diameter. The software output, besides the dynamic IFT data, includes the profile, volume, and surface area of the dynamic pendant liquid drop versus time. To validate our experimental results, prior to each experiment the whole system was cleaned by circulating toluene, acetone and then with deionized water, then flushed with nitrogen, and finally vacuumed. The IFT tests were repeated three times for dead/live oil samples with a same condition for each sample, and their average is reported in this study. The error in the IFT data at each temperature and pressure was $<0.2 \mathrm{mN} / \mathrm{m}$. The error analysis also showed that the maximum standard deviation of gas-oil IFT measurements in all experiments was about $\pm 0.2 \mathrm{mN} / \mathrm{m}$.

\section{Density measurements}

For the precise measurement of gas-oil IFT at a specific temperature and pressure, it is required that the oil density to be measured under the same conditions. 


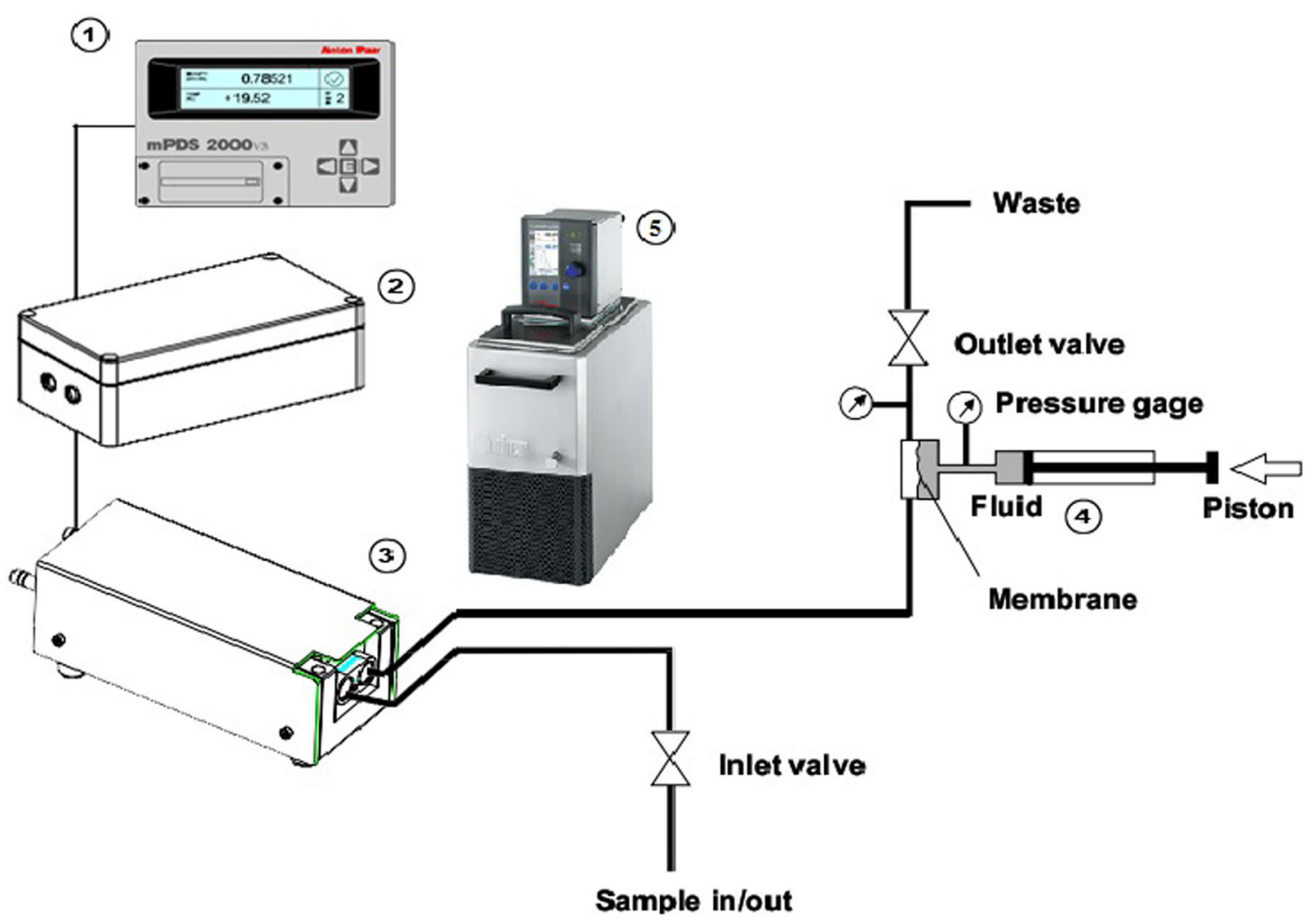

Fig. 3 Anton Paar apparatus for the density estimation, 1 mPDS 2000 V3, 2 interface module, 3 DMA HPM, 4 pressure generator, 5 heating and cooling bath (Riazi and Golkari 2016)

Density of crude oil and live oil was measured by a vibrating tube Anton Paar density meter at high-pressure and high-temperature conditions with high accuracy of $0.0005 \mathrm{~g} / \mathrm{ml}$ (Anton Paar Instruction Manual $\mathrm{GmbH}$ 2005). The schematic observation of the point out apparatus is shown in Fig. 3. The Anton Paar density meter has been formed from the four main components that is illustrated in Fig. 3. Temperature of the U-tube cell of DMA HPM is controlled by circulating fluid of heating/cooling bath which is able to keep the cell at the suitable temperature. The cell is connected to a highpressure vessel and a high-pressure pump, which injects the fluid into the cell at the desired pressure. Before of running the system for the density measurement, the U-tube cell and its connections are completely cleaned using toluene and acetone and then dried using nitrogen injection. The density meter device has been designed for measuring the density of the fluids at high pressure and temperature. It is capable of estimating the density at reservoir conditions. Before of the density measurement, the Anton Paar was calibrated by pure samples such as, nitrogen and dodecane at $313.15-393.15 \mathrm{~K}$ and deionized water at $313.15-353.15 \mathrm{~K}$ at different pressures (Zolghadr 2011).

\section{Results and discussion}

The results of the (live and crude) oil density measurement at temperature of 313.15 and $323.15 \mathrm{~K}$ are shown in Fig. 4. As it can be seen from Fig. 4, the oil densities vary linearly with pressure at a specific temperature. Density of live crude oil is less than that of dead oil with an average of $3 \%$ (for instance, $2.9 \%$ at $P=5 \mathrm{MPa}$ and $T=313.15 \mathrm{~K}$ ). This difference is due to the methane gas dissolved in the crude oil that makes oil lighter. As can be seen from Fig. 4, the slope variations of the live oil density are greater than that of the dead oil at test pressures conditions. This could partly due to the effect of pressure on the $\mathrm{CH}_{4}$ solubility in the crude oil. However, it should be noted that the live oil was prepared on a low gas-oil ratio at $P=4 \mathrm{MPa}$. Since the solubility variation of $\mathrm{CO}_{2}$ within the oil is insignificant at test pressure conditions (Sayegh et al. 1990), in this work, the densities of two oil samples are assumed the same as the dead/live crude oil density. In all of IFT tests, the $\mathrm{CO}_{2}$ density was considered equal to that of pure $\mathrm{CO}_{2}$, and it was extracted from National Institute of Standards and Technology source data at both temperatures and desired pressures ("NIST, Chemistry WebBook, NIST Standard Reference Database", 2014). 

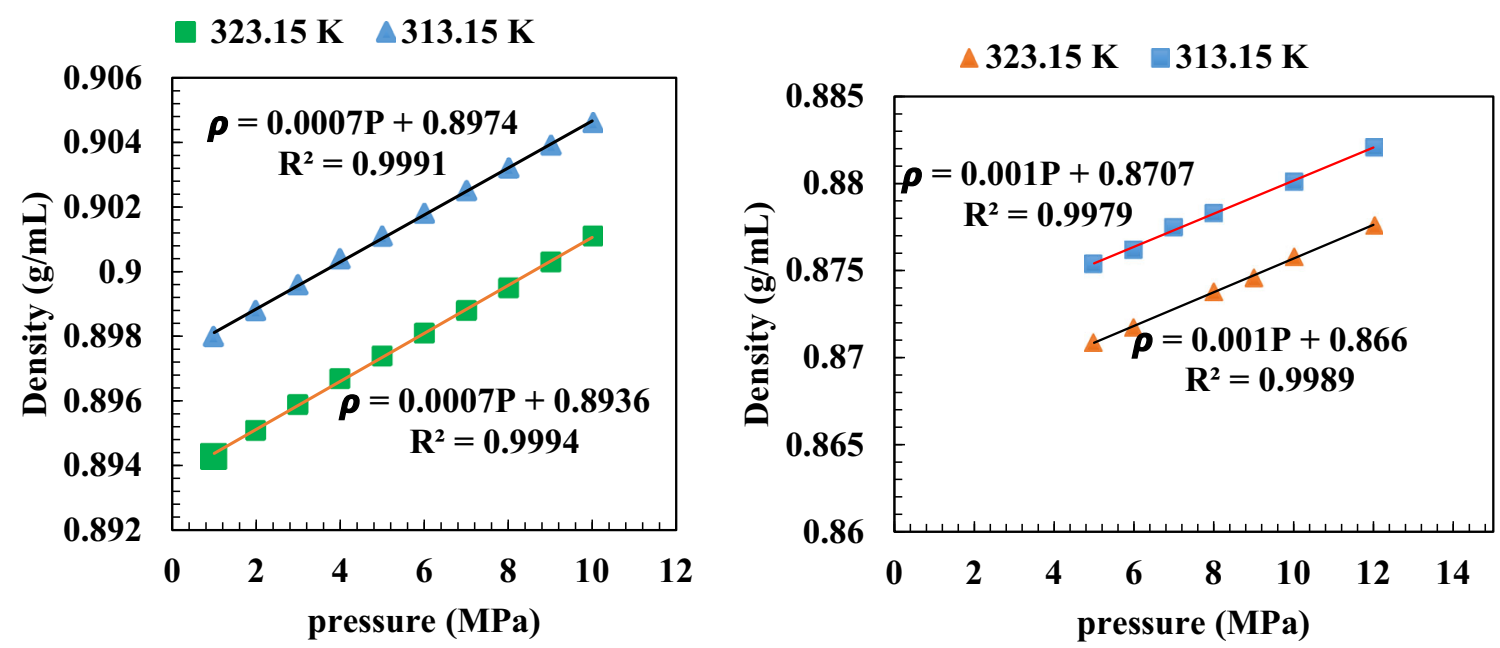

Fig. 4 Oil density measured at two temperatures of 313.15 and $323.15 \mathrm{~K}$ under different pressures for a crude oil and b live crude oil
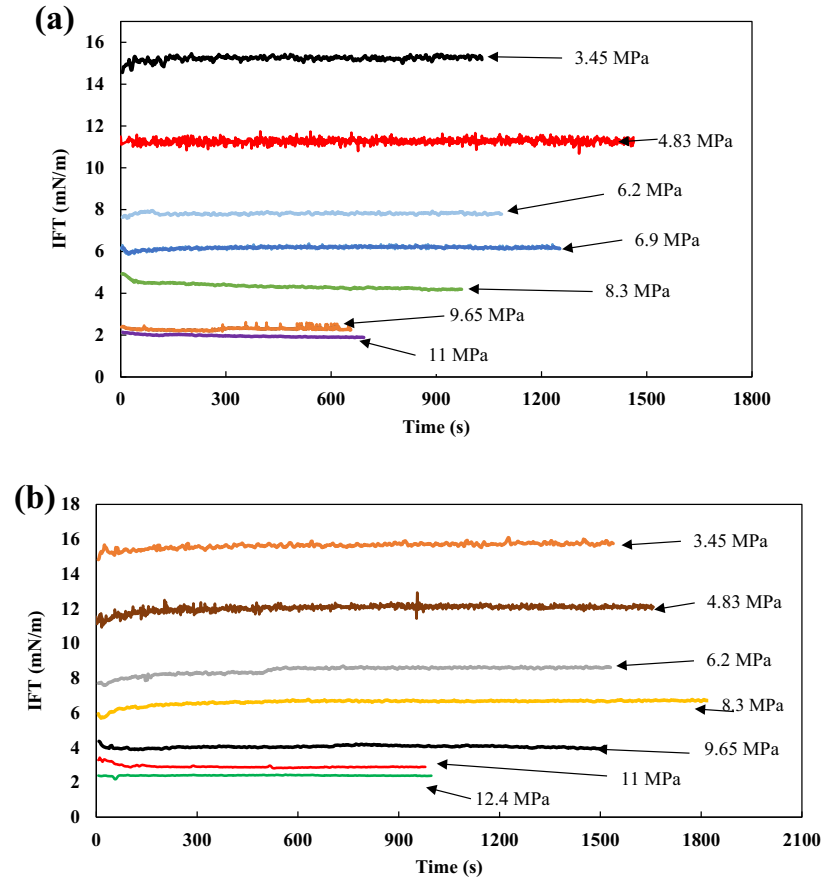

Fig. 5 Estimated interfacial tensions (IFTs) of a the crude oil- $\mathrm{CO}_{2}$ system and $\mathbf{b}$ the live oil- $\mathrm{CO}_{2}$ system, as a function of time under different pressure conditions at $313.15 \mathrm{~K}$

Since the pure $\mathrm{CO}_{2}$ density has a small difference with that of the $\mathrm{CO}_{2}$ equilibrium with oil, this assumption does not make a considerable error in the results (Zolghadr et al. 2013).

In Fig. 5a, b, the estimated IFTs between the dead/live oil and $\mathrm{CO}_{2}$ versus time are presented under various pressures at the temperature of $313.15 \mathrm{~K}$. The results show that dynamic IFT reaches an equilibrium value after a short time under different pressure conditions. As compared to the dynamic IFT data for dead oil at $313.15 \mathrm{~K}$, the

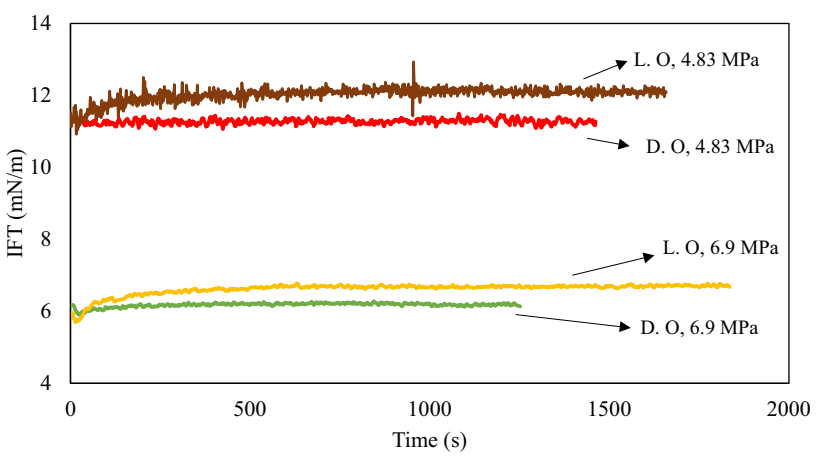

Fig. 6 Comparison of the dynamic IFT for two systems of live oil (L.O) and dead oil (D.O) at $313.15 \mathrm{~K}$

interfacial tension of live oil at $313.15 \mathrm{~K}$ shown in Fig. 6 is slightly higher under the similar pressure conditions. The likely reason could be due to the presence of methane in the live oil that consequently reduces the solubility of $\mathrm{CO}_{2}$ in the live oil than that in the dead oil.

For both the systems mentioned, the dynamic IFT decreases with pressure; however, the rate of reduction slightly decreases at higher pressure conditions. This could be due to the fact that the $\mathrm{CO}_{2}$ solubility at low pressures significantly improves by pressure, whereas at higher pressures $\mathrm{CO}_{2}$ solubility slightly increases with pressure. Asphaltene accumulation at the interface at higher pressure conditions could be another likely reason during which the interface becomes more rigid.

Also, as compared to the dynamic IFT data for dead oil at two temperatures (i.e., 313.15 and $323.15 \mathrm{~K}$ ) and 6.2 MPa in Fig. 7, one can be observed that the IFT values are higher at $T=323.15 \mathrm{~K}$ than those at $313.15 \mathrm{~K}$. This trend that was observed for other pressure conditions as well could be mainly due to smaller $\mathrm{CO}_{2}$ solubility in the crude oil at higher temperature (Ferworn et al. 1993). 


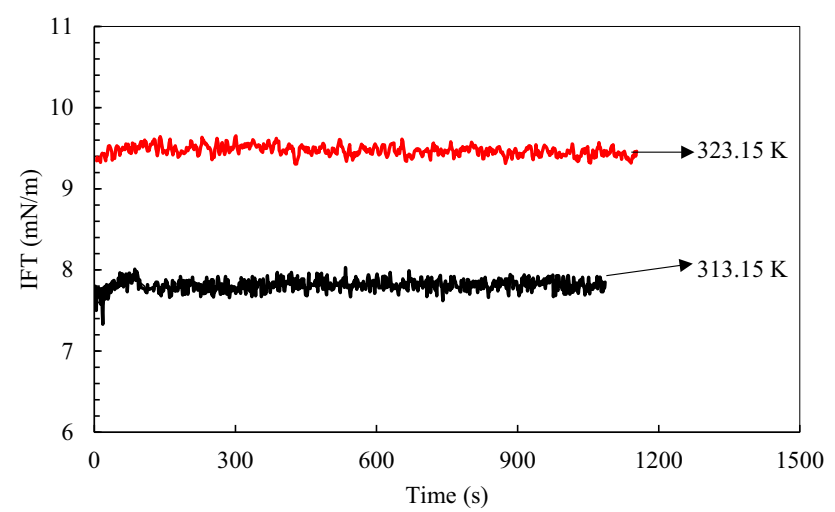

Fig. 7 Effect of temperature on the dynamic IFT of dead oil- $\mathrm{CO}_{2}$ system at $P=6.2 \mathrm{MPa}$

At the final of each dynamic interfacial tension (IFT) test, there is a constant value of interfacial tension that is related to as the equilibrium IFT. For a given temperature, the equilibrium value of IFT using their average values was estimated at the last moments. The experiments were performed for different pressures, and the equilibrium IFT data of the dead/live crude oil- $\mathrm{CO}_{2}$ systems were plotted versus pressure. The equilibrium IFTs of dead and live crude oil against the $\mathrm{CO}_{2}$ decrease with pressure, but they increase with temperature. That is related to the mechanism of $\mathrm{CO}_{2}$ dissolution in the crude oil that increases with pressure and, however, decreases with temperature. The $\mathrm{CO}_{2}$ solubility in oil results in oil swelling which improves the oil saturation and mobility and consequently increases the oil recovery efficiency (Al Jarba and Al Anazi 2009). The equilibrium IFT values of different observed pressure ranges were then extrapolated to zero IFT, which were formerly described as the VIT-MMP by extrapolating the first trend and VIT-FCMP by extrapolating the trend of last part data of the crude oil-gas system from which the minimum miscibility pressure (MMP) and first-contact miscibility pressure (FCMP) can be estimated, respectively. It can be seen that the VIT curve (Equilibrium IFT versus pressure curve) has been formed from three different slopes for the crude dead oil- $\mathrm{CO}_{2}$ system (see Fig. 8a). However, the results of Fig. 8b show that it changes with two different slopes for the live oil- $\mathrm{CO}_{2}$ system. These two different behaviors could be related to miscibility conditions of $\mathrm{CO}_{2}$ that is affected by the precipitation of heavy components (i.e., asphaltene and resin) at the asphaltenic crude oil-gas interface. In the literature, a slope change was discovered within the experimental conditions. After the onset condition of asphaltene precipitation, the slope of VIT data decreased significantly at a given pressure. This reduction was related to extraction of light component. Nevertheless, a comprehensive technical justification of the reason behind the slope change was not offered in the
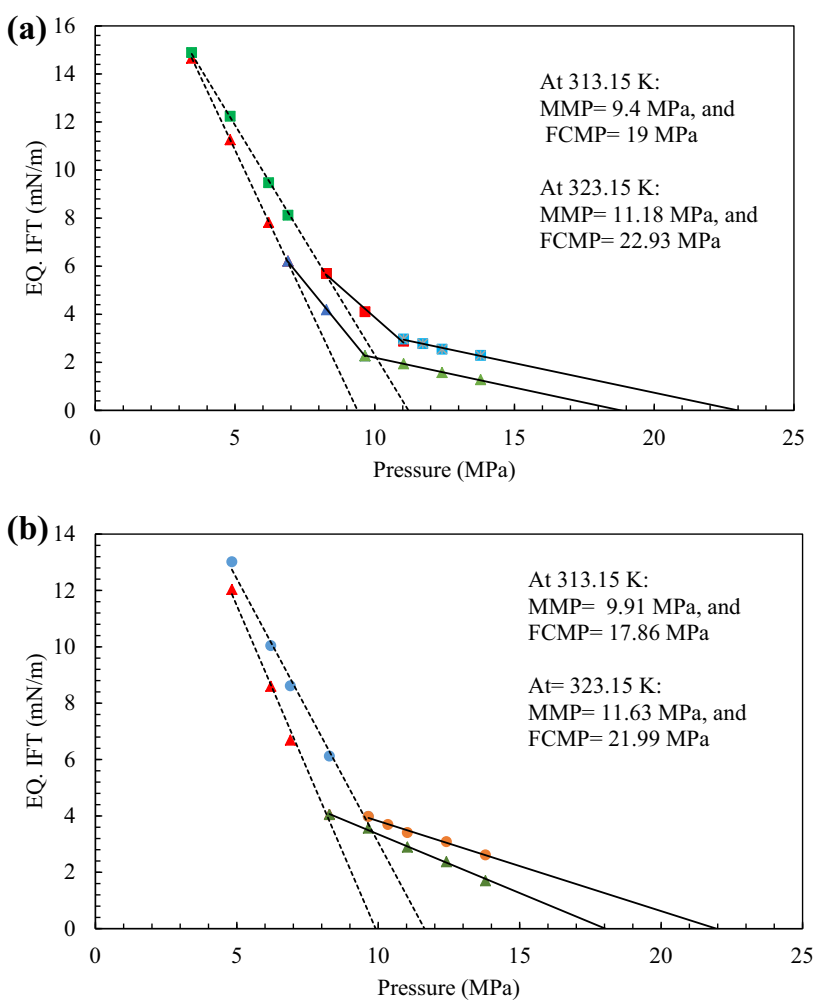

Fig. 8 Estimated MMP (dotted line) and FCMP (solid line) for a the dead oil- $\mathrm{CO}_{2}$ system: filled triangle test no. 1 at $313.15 \mathrm{~K}$, filled square test no. 2 at $323.15 \mathrm{~K}, \mathbf{b}$ the live oil- $\mathrm{CO}_{2}$ system: filled triangle test no. 3 at $313.15 \mathrm{~K}$, filled circle test no. 4 at $323.15 \mathrm{~K}$

literature (Wang and Gu 2011; Wang et al. 2010). Besides IFT studies, another research group investigated the conditions of miscibility for a crude oil through core flooding experiments, who comprehended that the point of slope change approaches to the asphaltene precipitation onset pressure (Cao and Gu 2013a). Dependency of the slope change of the VIT curve and the asphaltene precipitation has been previously confirmed by many studies (Ayirala and Rao 2006; Cao and Gu 2013a; Rao and Ayirala 2007; Rao and Lee 2003; Wang et al. 2010). Moreover, Nobakht et al. recently showed that slope change is attributed to the light-component extraction and variation of the oil composition at high pressures (Nobakht et al. 2008b). A review in literature is indicated that the slope change has not been detected for the pure hydrocarbon systems (Ayirala and Rao 2011; Zolghadr et al. 2013); however, in other experimental works, the slope change was observed when synthetic oil containing asphaltene was used (Georgiadis et al. 2010; Jaeger et al. 2002; Zolghadr et al. 2013). These results, to some extent, confirm that the slope change of VIT curve has a direct relation to the oil composition; nevertheless, more investigation is required to better understand the mentioned observation. Thus, the asphaltene precipitation and extraction of light component reduce 
Table 3 The correlations of IFT measurement for two samples of crude oil with $\mathrm{CO}_{2}$ at temperatures of 313.15 and $323.15 \mathrm{~K}$ and different pressure ranges

\begin{tabular}{lllll}
\hline Temperature $(\mathrm{K})$ & Oil sample & Region & $P:(\mathrm{MPa})$ & \multicolumn{1}{l}{$\begin{array}{l}R^{2} \\
P:(\mathrm{MPa})\end{array}$} \\
\hline 313.15 & & & IFT $=-2.4589 P+23.125$ \\
313.15 & Dead oil & First & $3.45 \leq P \leq 6.89$ & 0.9999 \\
313.15 & Dead oil & Second & $6.89 \leq P \leq 9.65$ & IFT $=-1.4283 P+16.038$ \\
323.15 & Dead oil & Third & $9.65 \leq P \leq 13.79$ & IFT $=-0.2417 P+4.599$ \\
323.15 & Dead oil & First & $3.45 \leq P \leq 8.27$ & IFT $=-1.9193 P+21.465$ \\
323.15 & Dead oil & Second & $8.27 \leq P \leq 11.03$ & IFT $=-1.0228 P+14.1$ \\
313.15 & Dead oil & Third & $11.03 \leq P \leq 13.79$ & IFT $=-0.2474 P+5.6751$ \\
313.15 & Live oil & First & $4.83 \leq P \leq 8.27$ & IFT $=-2.3338 P+23.13$ \\
323.15 & Live oil & Second & $8.27 \leq P \leq 13.79$ & IFT $=-0.4274 P+7.6322$ \\
323.15 & Live oil & First & $4.83 \leq P \leq 9.65$ & IFT $=-1.8697 P+21.762$ \\
\hline
\end{tabular}

the slope of the equilibrium IFT data versus pressure that consequently leads to increase in the pressure of $\mathrm{CO}_{2}$ miscibility (Escrochi et al. 2013). These are the reasons of the obtaining binary and ternary slops of the IFT data in this study. According to the equilibrium IFT data versus pressure shown in Fig. 8a, b, the correlations of IFT as a function of pressure using the linear regression at the different pressure ranges were determined. The IFT correlations for two samples of crude oil (i.e., dead and live oil) with $\mathrm{CO}_{2}$ at temperatures of 313.15 and $323.15 \mathrm{~K}$ and different pressures are presented in Table 3. As can be seen from this Table, the slope of IFT versus pressure curve of the dead/live oil- $\mathrm{CO}_{2}$ systems changes for both temperatures. For instance, at temperature of $313.15 \mathrm{~K}$, the decline of second and third slopes into the first slope is about of 42 and $90 \%$, respectively. In the case of live oil- $\mathrm{CO}_{2}$ data, the intermediate zone (i.e., second region) is eliminated. This is mainly due to reduction of heavy components for instance, asphaltene in the live crude oil.

To follow the purposes of this study, the estimated equilibrium IFT data between dead/live crude oil and $\mathrm{CO}_{2}$ at temperatures of 313.15 and $323.15 \mathrm{~K}$ and different pressures are shown in Fig. 8. As can be seen from this figure, the equilibrium IFT decreases with pressure, but increases with temperature for both oil samples. This could be due to the $\mathrm{CO}_{2}$ solubility in the crude oil that increases at higher pressure and decreases at higher temperature. The first region has the hint of lighter components positioned at the interface with $\mathrm{CO}_{2}$, while the second and third regions show the presence of heavier components such as asphaltene in crude oil after extraction of the light components by $\mathrm{CO}_{2}$ (Cao and Gu 2013b; Zolghadr et al. 2013).

As it can be seen from Fig. 8a, the estimated MMP increases for the dead oil- $\mathrm{CO}_{2}$ system when the temperature increases. According to the results presented in Fig. 8b, MMP of the live oil- $\mathrm{CO}_{2}$ system also increases with temperature. Figure $8 \mathrm{~b}$ indicates that the estimated MMP for the live crude oil- $\mathrm{CO}_{2}$ system is higher than that for the dead crude oil- $\mathrm{CO}_{2}$ system. In addition, Fig. 8a demonstrates that the estimated FCMP increases with increasing temperature for the dead oil- $\mathrm{CO}_{2}$ system. Also, Fig. 8b shows that FCMP value for the live oil- $\mathrm{CO}_{2}$ system increases when temperature increases.

As it can be seen from Fig. 8a, b, the estimated firstcontact miscibility pressure (FCMP) increases with temperature much more than the estimated MMP for the dead and live crude oil- $\mathrm{CO}_{2}$ systems. These two trends have also been already observed for the light crude oil- $\mathrm{CO}_{2}$ system by $\mathrm{Gu}$ et al. (2013). Based on the results of this study, it can conclude that both the measured MMP and FCMP are strongly dependent on temperature, regardless of the crude oil type- $\mathrm{CO}_{2}$ system. It can also be found from Fig. 8a, b that in general, the measured equilibrium IFT reduces gently with pressure at a higher temperature, which subsequently increases the FCMP. On the other hand, the slope of IFT versus pressure curve decreases with temperature at the same pressure region (see Table 3 ). This is due to the lower $\mathrm{CO}_{2}$ solubility in the crude oil at higher temperatures under the same equilibrium pressure conditions. In addition, density difference of two fluids is one of important variables that can influence the IFT data. It can be concluded that as temperature increases, the $\mathrm{CO}_{2}$ solubility decreases and consequently causes a larger density difference between two phases involved ( $\mathrm{Gu}$ et al. 2013). Therefore, for the system of crude oil and $\mathrm{CO}_{2}$, a higher pressure is required at higher temperature conditions, to develop the minimum miscibility and first or multi contact miscibility (i.e., MMP and MCMP or FCMP) (Cao and Gu 2013b; Gu et al. 2013).

In this study, the effect of oil composition is also investigated for two systems of live/dead oil- $\mathrm{CO}_{2}$. Using VIT method, the MMP and FCMP values estimated for 


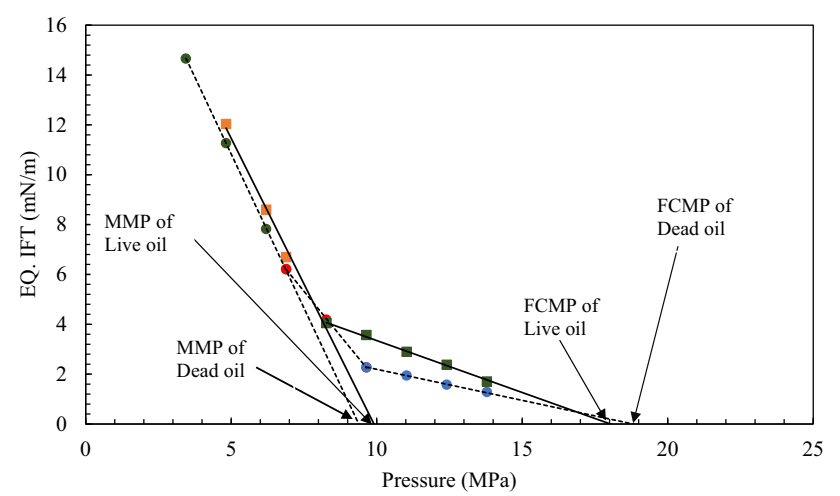

Fig. 9 Effect of oil composition on MMP and FCMP at 313.15 K, for the dead oil- $\mathrm{CO}_{2}$ system (dotted line): filled circle test no. 1 (including first, second and third regions), for live oil- $\mathrm{CO}_{2}$ system (solid line): filled square test no. 3 (including first, second regions)
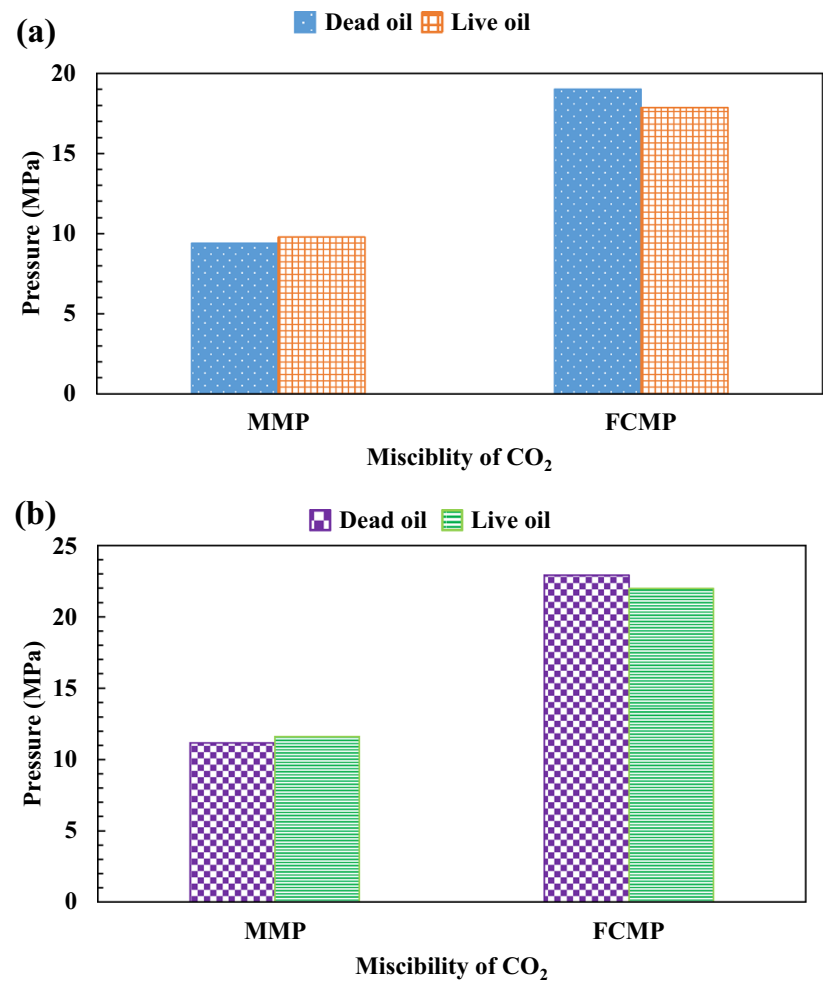

Fig. 10 Effect of oil composition on the estimated MMP and FCMP for the dead/live oil- $\mathrm{CO}_{2}$ systems a $T=313.15 \mathrm{~K}$, b $T=323.15 \mathrm{~K}$

both temperatures $\mathrm{K}$ are presented in Fig. 9, indicating three different pressure ranges for the dead crude oil- $\mathrm{CO}_{2}$ and two distinct pressure ranges for the live crude oil- $\mathrm{CO}_{2}$ where they are linearly reduced at different pressure ranges. As shown in Fig. 10a, b, the estimated MMP for the live oil- $-\mathrm{CO}_{2}$ system is only slightly higher than that for the dead oil- $-\mathrm{CO}_{2}$ system at the temperatures of 313.15 and $323.15 \mathrm{~K}$. Since the methane gas has been dissolved in dead oil sample, the mass transfer of carbon dioxide into the oil drop can hardly takes place. The similar behavior was observed for the synthetic HC gas-live oil system by $\mathrm{Gu}$ et al. (2013). The equilibrium IFT reduction in the first region is because the dissolution of $\mathrm{CO}_{2}$ in crude oil that it increases with increasing equilibrium pressure (see Fig. 9). However, the solubility of $\mathrm{CO}_{2}$ in the live crude oil is smaller than that for the dead oil. As a result, the live oil$\mathrm{CO}_{2}$ IFT becomes higher than that for the crude oil- $\mathrm{CO}_{2}$ system.

Moreover, it can be seen from Fig. 10a, b that FCMP is slightly dependent on the crude oil components including asphaltene (dead/live oil). In the second pressure range, the equilibrium IFT reduces with a gentler slope compared to that in the first region (see Fig. 9). It is understood that this behavior is because of accumulation and precipitation of asphaltene and light-component extraction from the crude oil into the gas phase $\left(\mathrm{CO}_{2}\right)$ (Escrochi et al. 2013; Kazemzadeh et al. 2015). As it can be seen from Fig. 9, in the last pressure zone (i.e., third range), the equilibrium IFTs also linearly decrease with a gentler slope compared to that in the first and the second regions. This different effect is due to the accumulation of colloidal particles at the interface of the two phases. In general, the composition of the gas phase and heavy components of crude oil is two key factors that can likely affect FCMP (Gu et al. 2013; Hemmati-Sarapardeh et al. 2013). Several researchers have also demonstrated that the pressure of miscibility conditions of the crude oil- $\mathrm{CH}_{4}$ system is higher than that for the crude oil- $\mathrm{CO}_{2}$ system (Kazemzadeh et al. 2015; Tathed et al. 2010). When the live oil drop is brought in contact with $\mathrm{CO}_{2}$, the methane gas is extracted from live oil drop due to pure $\mathrm{CO}_{2}$ as the bulk phase. Hence, the MMP of $\mathrm{CO}_{2}$ with live oil $(9.91 \mathrm{MPa})$ is higher than that with dead oil (9.4 MPa). It could be due to the fact that the live oil is saturated by methane, which is a light gas component. For the asphaltenic crude oil, asphaltene accumulation at the interface leads to slope reduction of the equilibrium IFT curve versus pressure that increases the pressure at the miscible conditions. Therefore, results are presented in Fig. 9. Figure 10a, b show that estimated FCMP slightly decreases for the live oil- $\mathrm{CO}_{2}$ system $(17.86 \mathrm{MPa}) \mathrm{com}$ pared to that for the dead oil- $\mathrm{CO}_{2}$ system $(19 \mathrm{MPa})$. As can be seen from Fig. 9, the intermediate zone of VIT curve for live oil has been eliminated. This is likely because of the presence of methane gas in the crude oil that makes the oil lighter than the original dead oil (see Fig. 4). Whereby the concentration of heavy components decreases in the live oil compared to that of dead oil. It should be noted that the results reported in this study for asphaltenic crude oil were similar to those presented by $\mathrm{Gu}$ et al. for lighter crude oil with less asphaltenic content.

To authenticate of the experimental data reported in this study, the measured data are compared with the results reported in the literatures. Hence, IFT between pure 
Table 4 Comparison of the experimental results of this study with literature data

\begin{tabular}{lllc}
\hline & \multicolumn{3}{l}{$T=323.15 \mathrm{~K}-n$-heptane- $\mathrm{CO}_{2}$ system } \\
\cline { 2 - 4 } & This work & $\begin{array}{l}\text { Ref (Jaeger and } \\
\text { Eggers 2012) }\end{array}$ & $\%$ difference \\
\hline MMP (MPa) & 8.4 & 8.5 & -1.1 \\
$\begin{array}{l}\text { DR, decline rate } \\
\left(10^{9} \mathrm{~m}\right)\end{array}$ & 1.9 & 1.81 & 5 \\
\hline
\end{tabular}

n-Heptane and $\mathrm{CO}_{2}$ was measured by the same research team at temperature of $323.15 \mathrm{~K}$ and different pressures (Kazemzadeh et al. 2015). The MMP of n-heptane- $\mathrm{CO}_{2}$ system using IFT values versus pressure according to the previously defined procedure was predicted and compared with the similar data in the literature. The results presented in Table 4, show a good agreement between the data of this study and the one in the literature (Jaeger and Eggers 2012).

\section{Conclusions}

From the results obtained from this experimental work, the following conclusions can be drawn:

1. The experimental results show that the equilibrium IFT of the dead and live oil- $\mathrm{CO}_{2}$ decreases with pressure; however it increases with temperature. These different behaviors of pressure and temperature on IFT are mainly due to the carbon dioxide dissolution into the crude oil that increases with pressure and decreases with temperature. The results show that at low pressures, the pressure effect on the equilibrium interfacial tension between the crude oil and $\mathrm{CO}_{2}$ is dominant compared to the temperature effect.

2. The increase of MMP and FCMP with temperature is related to the slope of the equilibrium IFT curve versus pressure in which the slope reduction is observed at the higher temperature. Thus, miscibility conditions of the crude oil- $-\mathrm{CO}_{2}$ system highly depend on temperature.

3. The estimated MMP of the live crude oil- $-\mathrm{CO}_{2}$ system is higher than that for the dead oil- $\mathrm{CO}_{2}$ system, because the methane gas has been dissolved in the dead oil sample. The equilibrium IFT reduction in the first region is related to the higher $\mathrm{CO}_{2}$ solubility in crude oil with increasing pressure. However, the solubility of $\mathrm{CO}_{2}$ in the live crude oil is smaller than that for the dead crude oil. Another likely reason could be caused by evaporation phenomenon through which the gas bulk becomes lighter and consequently miscible pressure increases.
4. According to the results obtained (Figs. 9, 10) temperature is a more pronounced parameter than oil composition on MMP and FCMP.

5. Live oil has a less FCMP compared to dead oil at the same temperature. This behavior is affected by two mechanisms including the asphaltene precipitation at the interface and extraction of light components from the crude oil by $\mathrm{CO}_{2}$ in these regions. These result in slope reduction of the IFT curve versus pressure. As a result, the pressure of $\mathrm{CO}_{2}$ miscibility conditions increases.

Acknowledgments Authors would like to thank Dr. M. Escrochi and Dr. A. Zolghadr for their valuable advices. We would also like to thank Mr. Y. Kazemzadeh and Dr. M. Lashkarblooki for their help over the course of this study. Special thanks also to the core analysis laboratory director, Ms. Meratian, for providing a suitable situation and work space.

Open Access This article is distributed under the terms of the Creative Commons Attribution 4.0 International License (http:// creativecommons.org/licenses/by/4.0/), which permits unrestricted use, distribution, and reproduction in any medium, provided you give appropriate credit to the original author(s) and the source, provide a link to the Creative Commons license, and indicate if changes were made.

\section{References}

Al Jarba M, Al Anazi BD (2009) A comparison study of the of the $\mathrm{CO}_{2}$-oil physical properties-literature correlations accuracy using visual basic modeling technique. Oil Gas Bus 60(5):287-291

Ali S, Thomas S (1996) The promise and problems of enhanced oil recovery methods. J Can Petrol Technol 35(7):57-63. doi:10. 2118/96-07-07

Alvarado V, Manrique E (2010) Enhanced oil recovery: an update review. Energies 3(9):1529-1575

Aycaguer A-C, Lev-On M, Winer AM (2001) Reducing carbon dioxide emissions with enhanced oil recovery projects: a life cycle assessment approach. Energy Fuels 15(2):303-308

Ayirala SC, Rao DN (2006) A new mechanistic Parachor model to predict dynamic interfacial tension and miscibility in multicomponent hydrocarbon systems. $\mathrm{J}$ Colloid Interface Sci 299(1):321-331

Ayirala SC, Rao DN (2011) Comparative evaluation of a new gas/oil miscibility-determination technique. J Can Petrol Technol 50(9-10):71-81

Benham AL, Dowden WE, Kunzman WJ (1960) Miscible fluid displacement-prediction of miscibility. Pet Trac AIME 219:229-237

Cao M (2012) Oil recovery mechanisms and asphaltene precipitation phenomenon in $\mathrm{CO}_{2}$ flooding processes. Faculty of Graduate Studies and Research, University of Regina, Regina

Cao M, Gu Y (2013a) Oil recovery mechanisms and asphaltene precipitation phenomenon in immiscible and miscible $\mathrm{CO}_{2}$ flooding processes. Fuel 109:157-166 
Cao M, Gu Y (2013b) Temperature effects on the phase behaviour, mutual interactions and oil recovery of a light crude oil- $\mathrm{CO}_{2}$ system. Fluid Phase Equilib 356:78-89

Cheng P, Li D, Boruvka L, Rotenberg Y, Neumann A (1990) Automation of axisymmetric drop shape analysis for measurements of interfacial tensions and contact angles. Colloids Surf 43(2):151-167

Danesh A (1998) PVT and phase behaviour of petroleum reservoir fluids, vol 47. Elsevier, Amsterdam

De Gennes P-G, Brochard-Wyart F, Quéré D (2004) Capillarity and wetting phenomena: drops, bubbles, pearls, waves. Springer, Berlin

Anton Paar Instruction Manual GmbH (2005) DMA HP density measuring cell for high pressure and high temperatures, Graz, Austria

Dong M, Huang S, Dyer SB, Mourits FM (2001) A comparison of $\mathrm{CO}_{2}$ minimum miscibility pressure determinations for Weyburn crude oil. J Petrol Sci Eng 31(1):13-22

Elsharkawy A, Poettmann F, Christiansen R (1992) Measuring minimum miscibility pressure: slim-tube or rising-bubble method? SPE paper 24114 presented at the 1992 SPE. Paper presented at the DOE symposium on enhanced oil recovery, Tulsa, OK, April

Escrochi M, Mehranbod N, Ayatollahi S (2013) The gas-oil interfacial behavior during gas injection into an asphaltenic oil reservoir. J Chem Eng Data 58(9):2513-2526

Fanchi JR (2005) Principles of applied reservoir simulation. Gulf Professional Publishing, Houston

Farzad I, Amani M (2012) An analysis of reservoir production strategies in miscible and immiscible gas injection projects. Adv Petrol Explor Dev 3(1):18-32

Ferworn KA, Svrcek WY, Mehrotra AK (1993) Measurement of asphaltene particle size distributions in crude oils diluted with n-heptane. Ind Eng Chem Res 32(5):955-959

Georgiadis A, Llovell F, Bismarck A, Blas FJ, Galindo A, Maitland GC, Trusler JM, Jackson G (2010) Interfacial tension measurements and modelling of (carbon dioxide + n-alkane) and (carbon dioxide + water) binary mixtures at elevated pressures and temperatures. J Supercrit Fluids 55(2):743-754

Ghorbani M, Momeni A, Safavi S, Gandomkar A (2014) Modified vanishing interfacial tension (VIT) test for $\mathrm{CO}_{2}$-oil minimum miscibility pressure (MMP) measurement. J Nat Gas Sci Eng 20:92-98

Green DW, Willhite GP (1998) Enhanced oil recovery. Richardson, Tex.: Henry L. Doherty Memorial Fund of AIME, Society of Petroleum Engineers, Texas

Gu Y, Hou P, Luo W (2013) Effects of four important factors on the measured minimum miscibility pressure and first-contact miscibility pressure. J Chem Eng Data 58(5):1361-1370

Gui X, Tang Z, Fei W (2010) $\mathrm{CO}_{2}$ capture with physical solvent dimethyl carbonate at high pressures. J Chem Eng Data 55(9):3736-3741

Hemmati-Sarapardeh A, Ayatollahi S, Ghazanfari M-H, Masihi M (2013) Experimental determination of interfacial tension and miscibility of the $\mathrm{CO}_{2}$-crude oil system; temperature, pressure, and composition effects. J Chem Eng Data 59(1):61-69

Hemmati-Sarapardeh A, Ayatollahi S, Zolghadr A, Ghazanfari M-H, Masihi M (2014) Experimental determination of equilibrium interfacial tension for nitrogen-crude oil during the gas injection process: the role of temperature, pressure, and composition. J Chem Eng Data 59(11):3461-3469

Holm L (1987) Miscible displacement. Petroleum Engineering Hand Book, Society of Petroleum Engineers, Richardson, Texas, pp 1-45

Holm L, Josendal V (1974) Mechanisms of oil displacement by carbon dioxide. J Petrol Technol 26(12):1,427-421438
IFT 700 (2013) For InterFacial tension determination, operating manual. VINCI Technologies, France

Jaeger PT, Eggers R (2012) Interfacial properties at elevated pressures in reservoir systems containing compressed or supercritical carbon dioxide. J Supercrit Fluids 66:80-85

Jaeger PT, Eggers R, Baumgartl H (2002) Interfacial properties of high viscous liquids in a supercritical carbon dioxide atmosphere. J Supercrit Fluids 24(3):203-217

Jafari Behbahani T, Ghotbi C, Taghikhani V, Shahrabadi A (2012) Investigation on asphaltene deposition mechanisms during $\mathrm{CO}_{2}$ flooding processes in porous media: a novel experimental study and a modified model based on multilayer theory for asphaltene adsorption. Energy Fuels 26(8):5080-5091

Jha KN (1985) A laboratory study of heavy oil recovery with carbon dioxide. Paper presented at the Technical Meeting/Petroleum Conference of The South Saskatchewan Section

Kazemzadeh Y, Riazi M (2013) Comparison between minimum miscibility pressure (MMP) of different gases using slim tube and rising bubble methods. Paper presented at the in Petroleum Technical Conference and Exhibition, Tehran

Kazemzadeh Y, Parsaei R, Riazi M (2015) Experimental study of asphaltene precipitation prediction during gas injection to oil reservoirs by interfacial tension measurement. Colloids Surf A 466:138-146

Kokal SL, Najman J, Sayegh SG, George AE (1992) Measurement and correlation of asphaltene precipitation from heavy oils by gas injection. J Can Petrol Technol 31(04):24-30. doi:10.2118/ 92-04-01

Lake LW (1989) Enhanced oil recovery. Prentice Hall, Englewood Cliffs, NJ

Leach M, Yellig W (1981) Compositional model studies- $\mathrm{CO}_{2}$ oildisplacement mechanisms. SPE J 21(01):89-97

Martin FD, Taber J (1992) Carbon dioxide flooding. JPT J Petrol Technol 44(4):396-400

Mathiassen $\mathrm{OM}$ (2003) $\mathrm{CO}_{2}$ as injection gas for enhanced oil recovery and estimation of the potential on the Norwegian continental shelf. Norwegian University of Science and Technology (NTNU), Department of Petroleum Engineering and Applied Geophysics, Trondheim

Moritis G (2004) EOR continues to unlock oil resources. Oil Gas J 102(14):49-52

Mungan N (1981) Carbon dioxide flooding-fundamentals. J Can Petrol Technol 20(1):87-92. doi:10.2118/81-01-03

Nielsen BB, Svrcek WY, Mehrotra AK (1994) Effects of temperature and pressure on asphaltene particle size distributions in crude oils diluted with n-pentane. Ind Eng Chem Res 33(5):1324-1330

NISOC Report, Ahvaze. south of Iran (2014)

NIST, Chemistry WebBook, NIST Standard Reference Database (2014)

Nobakht M, Moghadam S, Gu Y (2008a) Determination of $\mathrm{CO}_{2}$ minimum miscibility pressure from measured and predicted equilibrium interfacial tensions. Ind Eng Chem Res 47(22):8918-8925

Nobakht M, Moghadam S, Gu Y (2008b) Mutual interactions between crude oil and $\mathrm{CO}_{2}$ under different pressures. Fluid Phase Equilib 265(1):94-103

Orr FM, Jessen K (2007) An analysis of the vanishing interfacial tension technique for determination of minimum miscibility pressure. Fluid Phase Equilib 255(2):99-109

Rao DN (1997) A new technique of vanishing interfacial tension for miscibility determination. Fluid Phase Equilib 139(1):311-324

Rao DN, Ayirala SC (2007) Authors' response to the comments on "A new mechanistic Parachor model to predict dynamic interfacial tension and miscibility in multicomponent hydrocarbon systems" by FM Orr and K. Jessen. J Colloid Interface Sci 307(2):559-562 
Rao DN, Lee JI (2000a) Evaluation of minimum miscibility pressure and composition for Terra Nova Offshore Project using the new vanishing interfacial tension technique. Paper presented at the SPE/DOE Improved Oil Recovery Symposium

Rao DN, Lee JI (2000b) Miscibility evaluation for terra nova offshore field. Paper presented at the Canadian International Petroleum Conference

Rao DN, Lee JI (2002) Application of the new vanishing interfacial tension technique to evaluate miscibility conditions for the Terra Nova Offshore Project. J Petrol Sci Eng 35(3-4):247-262

Rao DN, Lee JI (2003) Determination of gas-oil miscibility conditions by interfacial tension measurements. J Colloid Interface Sci 262(2):474-482

Rao AB, Rubin ES (2002) A technical, economic, and environmental assessment of amine-based $\mathrm{CO}_{2}$ capture technology for power plant greenhouse gas control. Environ Sci Technol 36(20):4467-4475

Riazi M, Golkari A (2016) The influence of spreading coefficient on carbonated water alternating gas injection in a heavy crude oil. Fuel 178:1-9

Rojas G, Ali S (1988) Dynamics of subcritical $\mathrm{CO}_{2}$ /brine floods for heavy-oil recovery. SPE Reserv Eng 3(01):35-44

Rotenberg Y, Boruvka L, Neumann A (1983) Determination of surface tension and contact angle from the shapes of axisymmetric fluid interfaces. J Colloid Interface Sci 93(1):169-183

Saini D, Rao DN (2010) Experimental determination of minimum miscibility pressure (MMP) by gas/oil IFT measurements for a gas injection EOR project. Paper presented at the SPE Western Regional Meeting

Sarma HK (2003) Can we ignore asphaltene in a gas injection project for light-oils? Paper presented at the SPE international improved oil recovery conference in Asia Pacific

Sayegh S, Rao D, Kokal S, Najman J (1990) Phase behaviour and physical properties of Lindbergh heavy oil/ $/ \mathrm{CO}_{2}$ mixtures. J Can Petrol Technol 29(6):31-39. doi:10.2118/90-06-02
Schlumberger (2016) Schlumberger Oilfield Glossary. http://www. glossary.oilfield.slb.com/Terms/f/first-contact_miscibility.aspx. Accessed 15 July 2016

Simon R, Graue D (1965) Generalized correlations for predicting solubility swelling and viscosity behavior of $\mathrm{CO}_{2}$-crude oil systems. J Petrol Technol 17(01):102-106

Stalkup FI Jr (1983) Status of miscible displacement. J Pet Technol 35(04):815-826

Stalkup FI (1987) Displacement behavior of the condensing/vaporizing gas drive process. Paper presented at the SPE annual technical conference and exhibition

Tathed V, Dandekar AY, Patil SL (2010) Determination of minimum miscibility pressure using vanishing interfacial tension (VIT) in support of EOR for Alaska North Slope (ANS) heavy oil. Paper presented at the The Twentieth International Offshore and Polar Engineering Conference

Wang X, Gu Y (2011) Oil recovery and permeability reduction of a tight sandstone reservoir in immiscible and miscible $\mathrm{CO}_{2}$ flooding processes. Ind Eng Chem Res 50(4):2388-2399

Wang X, Zhang S, Gu Y (2010) Four important onset pressures for mutual interactions between each of three crude oils and $\mathrm{CO}_{2} \dagger$. J Chem Eng Data 55(10):4390-4398

Wylie PL, Mohanty KK (1999) Effect of wettability on oil recovery by near-miscible gas injection. SPE Reserv Eval Eng 2(06):558-564

Zanganeh P, Ayatollahi S, Alamdari A, Zolghadr A, Dashti H, Kord S (2012) Asphaltene deposition during $\mathrm{CO}_{2}$ injection and pressure depletion: a visual study. Energy Fuels 26(2):1412-1419

Zolghadr A (2011) Determination of optimum gas injection conditions in EOR process by interfacial tension investigation. M. Sc. thesis, Shiraz University, Shiraz, Iran

Zolghadr A, Escrochi M, Ayatollahi S (2013) Temperature and composition effect on $\mathrm{CO}_{2}$ miscibility by interfacial tension measurement. J Chem Eng Data 58(5):1168-1175 